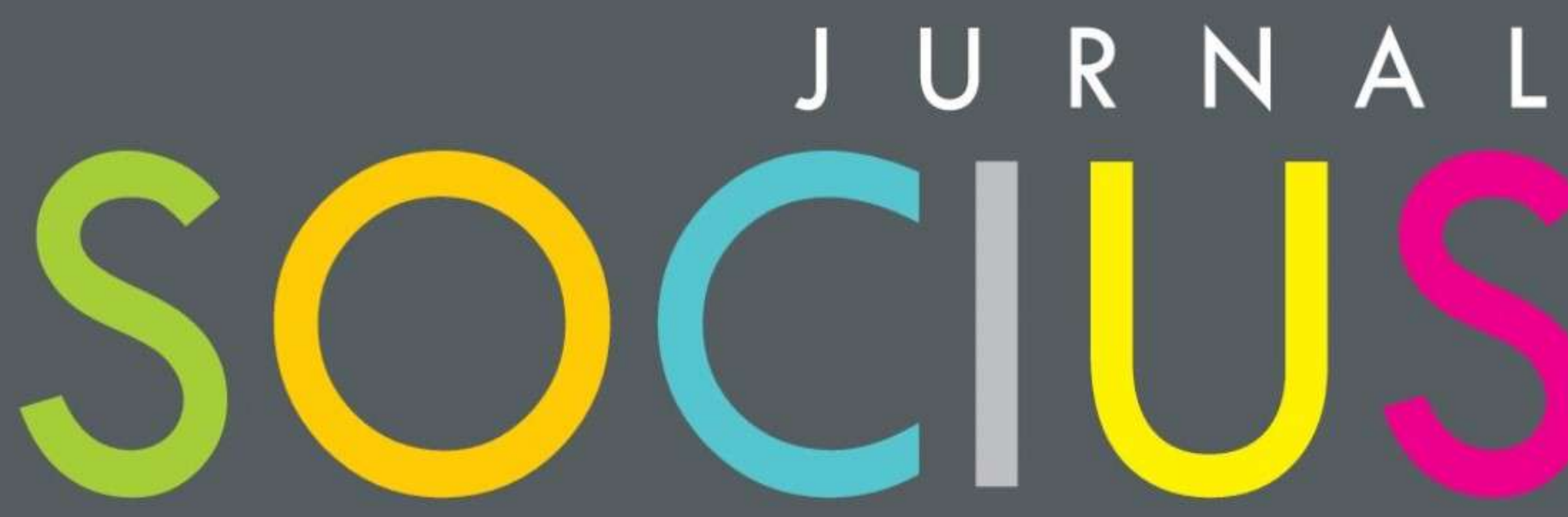

Journal of Sociology Research and Education

DITERBITKAN OLEH :

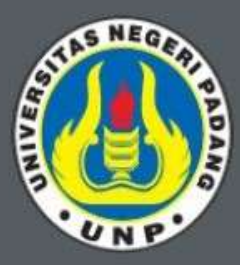

LABOR JURUSAN SOSIOLOGI FAKULTAS ILMU SOSIAL UNIVERSITAS NEGERI PADANG

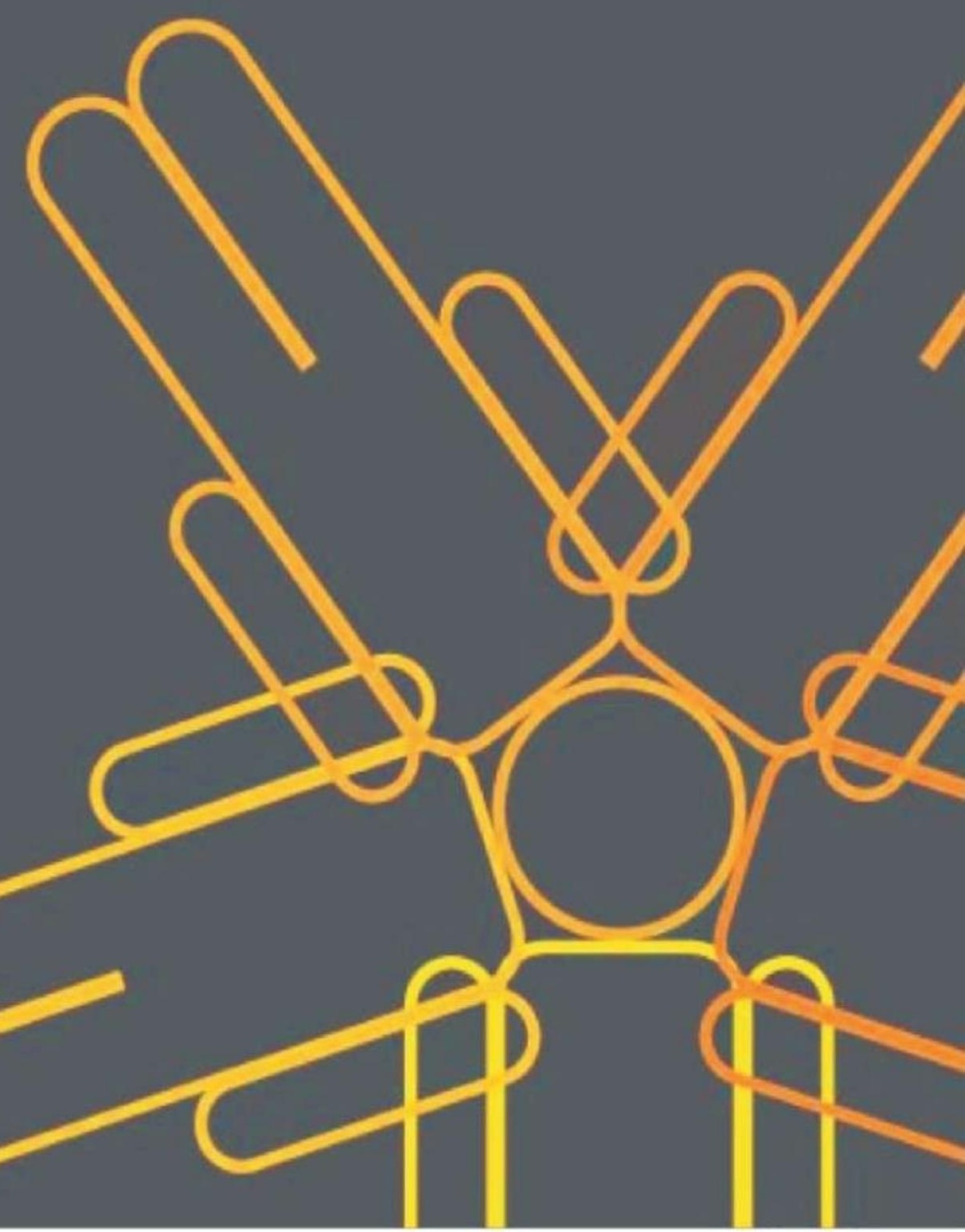




\section{SOCIUS}

Vol. 6, No.1, Th. 2019

ISSN : 2356-4180 (cetak)

2442-8663 (online)

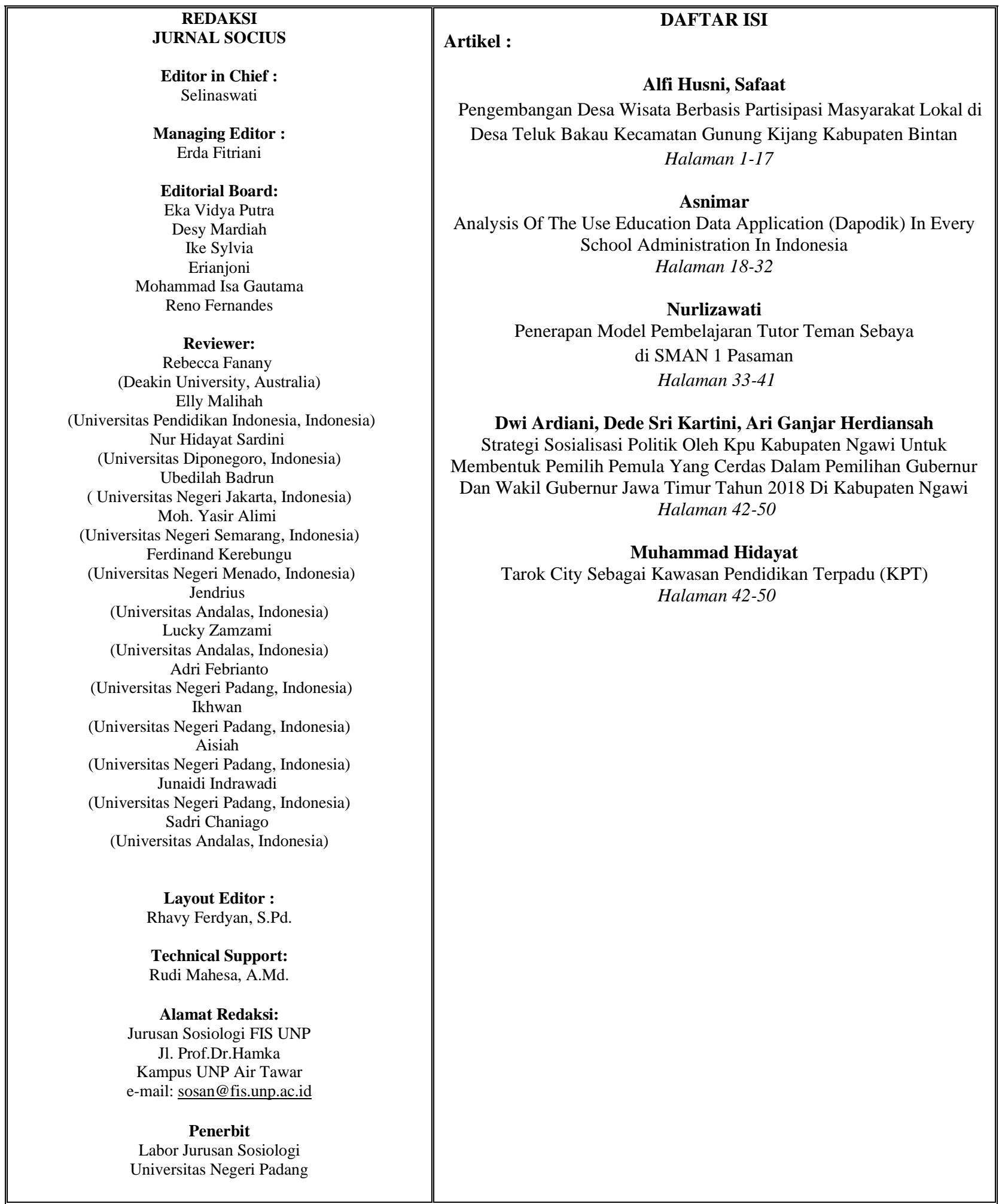




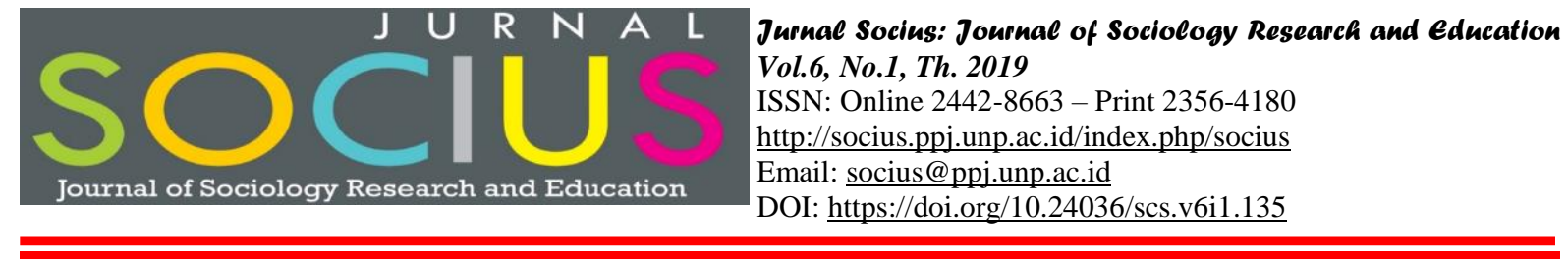

\title{
PENGEMBANGAN DESA WISATA BERBASIS PARTISIPASI MASYARAKAT LOKAL DI DESA TELUK BAKAU KECAMATAN GUNUNG KIJANG KABUPATEN BINTAN
}

\author{
Alfi Husni ${ }^{1}$, Safaat ${ }^{2}$ \\ 1,2 STISIPOL Raja Haji Tanjungpinang \\ Email: alfi.husni86@gmail.com mat.safaat@gmail.com
}

\begin{abstract}
Abstrak
Pengembangan desa wisata membutuhkan partisipasi masyarakat lokal dalam keseluruhan tahap pengembangan mulai tahap perencanaan, implementasi, dan pengawasan. Realitas menunjukkan bahwa pengabaian partisipasi masyarakat sering terjadi. Penelitian ini bertujuan mengkaji keterlibatan masyarakat lokal dalam pengembangan desa wisata dan merumuskan model pengembangan desa wisata yang mengedepankan partisipasi masyarakat lokal. Penelitian dalam tulisan ini dilakukan di desa wisata Teluk Bakau, Kecamatan Gunung Kijang, Kabupaten Bintan. Pengumpulan data dilakukan dengan cara observasi, wawancara mendalam, dan studi literatur. Metode analisis yang digunakan adalah analisis deskriptif kualitatif. Tulisan ini menunjukkan bahwa pengembangan desa wisata di Desa Teluk Bakau belum melibatkan masyarakat lokal. Peranan pemerintah terlihat dominan, padahal bila mengacu pada pendekatan tata kelola pemerintah yang bersih dan berkelanjutan peran pemerintah diharapkan menjadi fasilitator dengan memberikan peran dan manfaat yang lebih besar kepada masyarakat lokal. Kemauan politik pemerintah untuk mengurangi perannya dalam pengembangan desa wisata dengan membuka ruang bagi masyarakat untuk berpartisipasi.
\end{abstract}

Kata Kunci: Pengembangan, Desa Wisata, Partisipasi, Masyarakat Lokal

\section{Abstract}

The development of a tourist village requires the participation of local communities in the overall development phase from the planning, implementation and supervision stage. However, in reality there is often a neglect of community participation. This study aims to examine the involvement of local communities in the development of tourist villages and formulate models of village tourism development that prioritizes local community participation. Research in this paper is done in the tourist village of Bakau Bay, Gunung Kijang District, Bintan Regency. Data collection was done by observation, in-depth interview, and literature study. The analytical method used is qualitative descriptive analysis. This paper shows that the development of tourist village in Teluk Bakau Village has not involved local community. The role of the government is seen as dominant, but when it refers to a clean and sustainable government governance approach, the role of government is expected to become a facilitator by providing greater role and benefit to the local community. It takes the political will of the government to reduce its role in the development of tourist villages by opening space for the community to participate.

Keywords: Development, Tourism Village, Participation, Local Communities

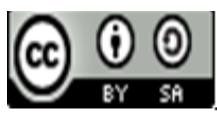

Received: January 8, 2019

Revised: April 4, 2019

Available Online: June 28, 2019

Jurnal Socius: Journal of Sociology Research and Education Vol. 6, No.1, Th. 2019

ISSN: Online 2442-8663 - Print 2356-4180 


\section{Pendahuluan}

Pariwisata merupakan sebuah industri yang perkembangannya kian pesat setiap tahunnya. Indonesia sektor pariwasata dikembangkan sebagai sektor yang menjanjikan serta mendatangkan pendapatan besar bagi negara terlebih di daerah-daerah yang memiliki sumber daya alam maupun sumber daya budaya yang melimpah. Berbagai potensi digali untuk menarik minat para wisatawan untuk datang berkunjung sehingga diharapkan mampu meningkatkan kesejahteraan masyarakat. ${ }^{1}$

Partisipasi masyarakat dalam pembangunan merupakan hal yang penting ketika diletakkan atas dasar keyakinan bahwa masyarakat yang paling tahu apa yang dibutuhkan. Partisipasi hakiki melibatkan masyarakat dalam keseluruhan tahapan pengembangan, mulai dari proses perencanaan, pengambilan keputusan, dan pengawasan program pengembangan desa wisata. Keikutsertaan masyarakat dalam perencanaan desa wisata dapat mendorong mereka berpartisipasi aktif dalam pelaksanaan dan pengawasan.

Desa Teluk Bakau sebagai salah satu destinasi pariwisata di Kabupaten Bintan, Provinsi Kepulauan Riau banyak memiliki keunikan wisata yang khas. Keunikan dan potensi pariwisata yang ada di Desa Teluk Bakau yang dikembangkan sebagai salah satu destinasi pariwisata berbasiskan pada budaya serta ditunjang oleh keindahan alam yang sangat menarik. Harapan untuk mendapatkan keuntungan dari kegiatan pariwisata kemudian diwujudkan oleh masyarakat melalui penyediaan layanan-layanan pariwisata untuk melengkapi kebutuhan wisatawan yang berkunjung seperti sarana pembangunan akomodasi pariwisata seperti tempat penginapan yang menyediakan keindahan alam yang bernuansa bahari dan budaya khas Melayu. Dari sini masyarakat Desa Teluk Bakau memperoleh keuntungan terutama finansial yang cukup besar.

Namun, kenyataan di lapangan menunjukkan bahwa pengembangan Desa Wisata belum berpihak kepada masyarakat Desa Teluk Bakau. Contohnya masyarakat Desa Teluk Bakau yang berprofesi sebagai nelayan semakin jauh untuk ke pantai. Para warga yang berprofesi sebagai nelayan harus menempuh jarak sejauh 5-10 Km untuk menuju tempat berlabuh sampan atau pompong yang menjadi alat transportasi mereka untuk mencari atau membawa hasil tangkapan ikan. Masyarakat yang beraktifitas sebagai nelayan di larang untuk melaut di lokasi wisata. Penyebabnya adalah tingginya tingkat pembangunan usaha akomodasi pariwisata dengan jumlah lahan yang sangat terbatas.

Hal ini sangat dirasakan oleh warga desa Teluk Bakau, apalagi pembangunan pariwisata yang mengeksploitasikan alih fungsi lahan pesisir semakin gencar dilakukan oleh pihak pariwisata. Warga Desa Teluk Bakau semakin khawatir dengan keadaan ini. Mereka beranggapan bahwa untuk kedepannya mereka tidak bisa lagi menjalankan rutinitas mereka sebagai nelayan, karena sepanjang daerah pesisir pantai sudah dipagar oleh pihak pariwisata.

Kebijakan pemerintah lebih berpihak kepada kaum kapitalis (investor). Investor dibiarkan membangun fasilitas wisata berupa villa dan resort di pinggir pantai tanpa melakukan kesepakatan terlebih dahulu dengan masyarakat Desa Teluk Bakau. Pembangunan vila dan resort bermakna bahwa kepentingan ekonomi lebih diutamakan daripada kepentingan kelestarian alam dan budaya. Kondisi ini terjadi karena pembiaran yang dilakukan pengambil kebijakan, walaupun alam dan budaya dikorbankan demi kepentingan bisnis.

Masuknya kaum kapitalis dalam pengembangan desa wisata membangun area kompetisi ekonomi. Kompetisi tidak saja dalam perebutan lapangan pekerjaan juga dalam hal modal. Kelompok kapitalis lokal bersaing dengan pemodal kuat dari luar desa bahkan berasal dari luar negara. Jika kondisi ini dibiarkan, maka akan menimbulkan ketidakadilan ekonomi

\footnotetext{
${ }^{1}$ Undang-Undang Republik Indonesia Nomor 10 Tahun 2009 tentang Kepariwisataan

Jurnal Socius: Journal of Sociology Research and Education Vol. 6, No.1, Th. 2019 
antara masyarakat lokal dengan pendatang. Ketidakadilan berpotensi terjadinya konfik. Oleh karena itu, memberi ruang gerak bagi tumbuhnya ekonomi kerakyatan sangat diperlukan, karena kenyamanan desa wisata Teluk Bakau akan dipertaruhkan. Pariwisata dapat menghancurkan sendi-sendi kehidupan masyarakat desa.

Tulisan ini bertujuan untuk mengkaji keterlibatan masyarakat lokal dalam pengembangan desa wisata dan mengkaji model pengembangan desa wisata berbasis partisipasi masyarakat lokal. Kajian ini diharapkan dapat meningkatkan akselerasi pengembangan desa wisata yang mampu merangkul semua pemangku kepentingan agar dapat berperan strategis dalam pengembangan desa wisata. Pihak terkait dapat berpartisipasi dalam peningkatan kompetensi masyarakat lokal untuk pemberdayaan masyarakat lokal.

\section{Metodologi Penelitian}

Penelitian ini menggunakan teori partisipasi yang digunakan untuk mengkaji keterlibatan masyarakat lokal dalam pengembangan desa wisata di Desa Teluk Bakau dan mengkaji model pengembangan desa wisata berbasis partisipasi masyarakat lokal. Makna partisipasi adalah sebagai kekuatan yang dimiliki oleh masyarakat untuk mengatasi persoalannya pada masa kini guna mencapai kehidupan yang lebih baik pada masa mendatang.

Secara umum partisipasi dapat dimaknai sebagai hak warga masyarakat untuk terlibat dalam proses pengambilan keputusan pada setiap tahapan pembangunan, mulai dari perencanaan, pelaksanaan, pengawasan, dan pelestarian. Masyarakat bukanlah sekadar penerima manfaat atau objek belaka, melainkan sebagai subjek pembangunan. ${ }^{2}$

Partisipasi dapat membuat masyarakat, penduduk melakukan berbagai kegiatan, baik itu berskala lokal maupun nasional. Partisipasi yang dilakukan masyarakat berbeda-beda tingkatannya, akibat dari perbedaan skala kegiatan. Partisipasi itu antara lain, partisipasi karena paksaan (manipulative participation), partisipasi dengan kekuasaan dan ancaman (coercive participation), partisipasi karena adanya dorongan (indiced participation), partisipasi yang bersifat pasif (passive participation) dan partisipasi secara spontan (spontaneous participation). ${ }^{3}$

Partisipasi merupakan redistribusi kekuatan, yang memungkinkan kaum terpinggirkan secara ekonomi dan politik untuk dilibatkan dalam perencanaan pembangunan masa depan. Makna partisipasi yang mengacu pada pendapat Arnstein adalah kekuatan yang dimiliki oleh masyarakat untuk mengatasi persoalannya pada masa kini guna mencapai kehidupan yang lebih baik pada masa mendatang. ${ }^{4}$

Strategi pelaksanaan partisipasi dicapai dengan cara melibatkan masyarakat dalam sharing informasi, merumuskan tujuan, menentukan kebijakan, mengalokasikan sumbersumber pendanaan, mengoperasikan program, serta mendistribusikan manfaat yang diperoleh. Masyarakat dilibatkan sejak tahap perencanaan hingga implementasi dan pemerataan hasilhasilnya. ${ }^{5}$

Berdasarkan pandangan para ahli yang telah dikemukakan tersebut dapat disimpulkan bahwa pembangunan pariwisata berbasis masyarakat, aspek partisipasi merupakan isu mendasar. Partisipasi masyarakat lokal merupakan pijakan awal terhadap berbagai dampak strategis yang terkait dalam pengembangan desa wisata berbasis masyarakat. Partisipasi

\footnotetext{
${ }^{2}$ Cohen, JM, dan N.T. Uphoff, 1977. Rural Development Participation. Cornell University RDCCIS: New York.

${ }^{3}$ Tosun, C. 2000. Limits to community participation in the tourism developmentprocess in developing countries. Turkey: Bilkert University.

${ }^{4}$ Arnstein, S.R.1969. A Ladder OfCitizen Participation JAIP. Vol 35.No 4, pp 216--224 dilihat pada http;// LithgowSchmidt/Sherry-arnstein/ ladder-of-citizen participation. Pdf tanggal 30 Oktober 2009.

${ }^{5}$ Abe, A. 2002. Perencanaan Daerah Partisipatif. Solo: Pondok Edukasi.
}

Jurnal Socius: Journal of Sociology Research and Education Vol. 6, No.1, Th. 2019 
masyarakat menjadi penting bagi pencapaian desa wisata yang berkelanjutan dan bagi realisasi desa wisata yang berkualitas.

Kajian pengembangan desa wisata yang berbasis partisipasi masyarakat ini dilakukan dengan tiga cara yakni (1) Observasi ke lokasi penelitian untuk merekam perilaku atau kegiatan masyarakat yang selanjutnya diolah untuk mendapatkan data penelitian. Pengamatan terhadap lokasi penelitian dilakukan dengan mengamati secara langsung potensi dan daya tarik wisata, aspek sarana dan prasarana serta aspek fisik di Desa Teluk Bakau, (2) Wawancara mendalam (in-depth interview) untuk mengumpulkan data secara detail dari informan dan (3) Studi literatur untuk mengungkapkan berbagai teori-teori yang relevan dengan permasalahan yang sedang dihadapi/diteliti sebagai bahan rujukan dalam pembahasan hasil penelitian.

Kajian pengembangan desa wisata yang berbasis partisipasi masyarakat ini menggunakan metode pendekatan kualitatif. Pendekatan ini digunakan sebagai upaya untuk mengungkapkan fenomena secara mendalam yang digali melalui pandangan dan pengalaman masyarakat. Kelebihan pendekatan ini bisa mendapatkan perspektif yang lebih alami dari suatu kehidupan masyarakat dan membuka peluang untuk pendalaman yang lebih rinci dari pandangan-pandangan individu dalam masyarakat. ${ }^{6}$

Data yang digunakan di dalam studi ini adalah data primer dan data sekunder. Untuk menghasilkan data primer digunakan wawancara individu untuk memperoleh pandanganpandangan dan informasi mengenai pengalaman-pengalaman keikutsertaan masyarakat dalam proses pengembangan desa wisata. Teknik ini sangat bermanfaat dalam penelitian sosial karena wawancara mendalam dapat menggali keterangan dan pandangan serta pengalaman masyarakat lebih mendalam. Panduan wawancara digunakan sebagai acuan untuk mendapatkan data dari orang-orang yang menjadi informan.

Wawancara dan pengamatan lapangan dilakukan dengan informan terpilih seperti, tokoh masyarakat, pemilik rumah makan dan penginapan, para nelayan, dan pemilik lahan pinggir pantai yang telah dijual kepada investor. Keseluruhan jumlah informan dalam studi ini sebanyak 10 orang. Pemilihan informan dilakukan secara snowball sampling, dengan tetap mempertimbangkan keterwakilan unsur masyarakat.

Selain data primer dari wawancara, pengamatan langsung juga digunakan. Kombinasi hasil wawancara mendalam dan pengamatan langsung dalam penelitian kualitatif dapat menghasilkan data komprehensif dan bermakna. Selain data primer, digunakan juga data sekunder. Data sekunder yang digunakan berasal dari buku, laporan terbitan pemerintah, jurnal-jurnal, koran, website, dan sumber-sumber lain. Ketersediaan data di Desa Teluk Bakau cukup lengkap dan sangat membantu studi ini. Semua data dikumpulkan dan dianalisis dengan metode analisis deskriptif kualitatif dan analisis SWOT. Data diinterpretasikan dan dianalisis melalui evaluasi, justifikasi, dan dibahas sesuai dengan tinjauan pustaka dan dibandingkan dengan data yang ada.

\footnotetext{
${ }^{6}$ Lewis,J. 2003. Design Issues.In Qualitative ResearchPractice:aGuide forSocial Science Student Researcher(eds.)Jane Ritchie and Janes Lewis.London: SAGEPublications
}

Jurnal Socius: Journal of Sociology Research and Education Vol. 6, No.1, Th. 2019 


\section{Hasil dan Pembahasan}

\section{Gambaran Umum Desa Teluk Bakau}

Teluk Bakau merupakan salah satu desa yang ada di Kecamatan Gunung Kijang, Kabupaten Bintan, provinsi Kepulauan Riau, Indonesia. Wilayah Desa Teluk Bakau merupakan salah satu destinasi wisata asing yang sangat diminati yang disebabkan oleh keindahan alam baharinya. Sebagian besar penduduk Desa Teluk Bakau berprofesi sebagai nelayan. Letak wilayah Desa Teluk Bakau antara lain: a) Sebelah Utara: Desa Malang Rapat, b) Sebelah Selatan: Kelurahan Kawal, c) Sebelah Barat: Kelurahan Teluk Sebong, d) Sebelah Timur: Desa Pulau Mapur.

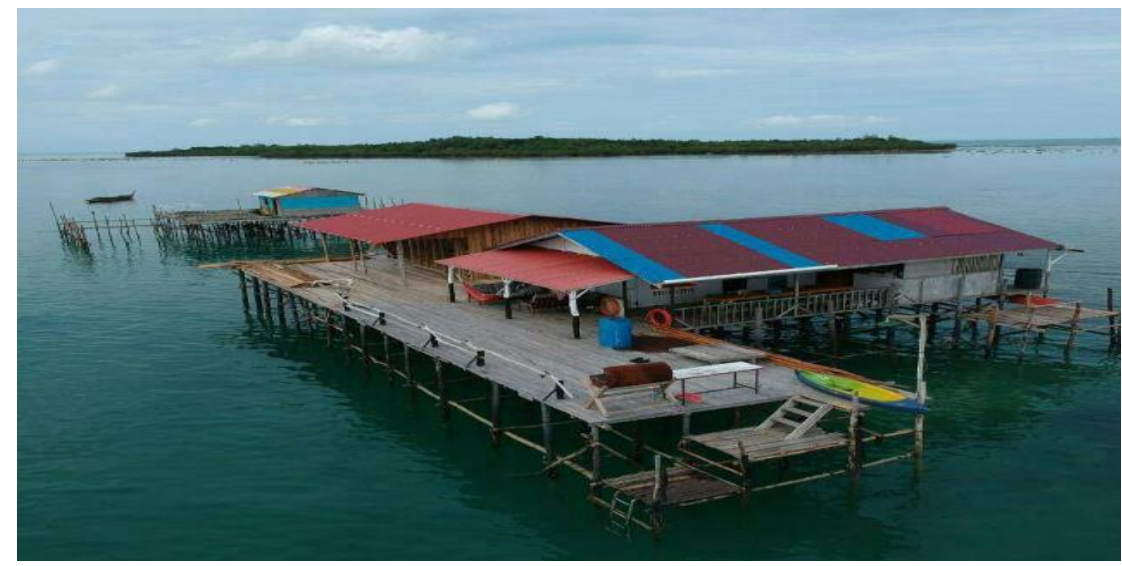

Gambar 1. Potensi Wisata Bahari di Desa Teluk Bakau/wisata Snorkeling dan diving

Di sekitar lokasi Desa Teluk Bakau terdapat beragam tempat wisata seperti resort dan tempat peranginan yang disediakan untuk para pengunjung atau wisatawan asing maupun lokal. Beberapa industri pariwisata yang ada di wilayah Desa Teluk Bakau antara lain, seperti Agro Risort, White Island, Nikoi Island, Spa Villa, Gurindam Risort, Sahid Bintan Hotel, dan wisata bawah laut atau snorkling.

\section{Potensi Wisata di Desa Teluk Bakau}

Potensi wisata menurut Mariotti dalam Yoeti (1983) adalah segala sesuatu yang terdapat di daerah tujuan wisata, dan merupakan daya tarik agar orang-orang mau datang berkunjung ke tempat tersebut. Wisnawa (2011) juga menjelaskan bahwa potensi wisata adalah sesuatu yang dapat dikembangkan menjadi daya tarik sebuah destinasi wisata. ${ }^{7}$ Dalam penelitian ini potensi wisata yang ada di Desa Teluk Bakau adalah potensi alam yaitu wisata bahari yang sangat memukau para pengunjungnya.

\section{Potensi Alam}

Potensi alam yang dimaksud adalah keadaan dan jenis flora dan fauna suatu daerah, bentang alam suatu daerah, misalnya pantai, hutan, dan lain-lain (keadaan fisik suatu daerah). Kelebihan dan keunikan yang dimiliki oleh alam jika dikembangkan dengan memperhatikan keadaan lingkungan sekitarnya niscaya akan menarik wisatawan untuk berkunjung ke destinasi wisata. Potensi daya tarik alam yang dimiliki Pulau Samalona berupa; pantai dengan pasir

\footnotetext{
${ }^{7}$ Yoeti, Oka A. 2002. Perencanaan Strategis Pemasaran Daerah Tujuan Wisata.Jakarta: PT. Pradnya Paramita

Jurnal Socius: Journal of Sociology Research and Education Vol. 6, No.1, Th. 2019

ISSN: Online 2442-8663 - Print 2356-4180

Copyright $\subset 2019$, Jurnal Socius
} 
putih, laut dengan biota laut dan karangnya, serta panorama matahari terbit (sunrise) dan terbenam (sunset). ${ }^{8}$

Desa Teluk Bakau, adalah salah satu desa yang terdapat di Provinsi Kepulauan Riau, tepatnya di wilayah Kecamatan Gunung Kijang Kabupaten Bintan. Desa Teluk Bakau secara geografis terletak di wilayah pesisir pantai. Salah satu yang menarik dari Desa Teluk Bakau ini adalah, keindahan wisata baharinya sehingga mampu menarik perhatian para wisatawan atau turis-turis baik dari luar negeri maupun luar daerah untuk berkunjung dengan tujuan menikmati langsung keindahan wisata baharinya (Gambar 2).

Menikmati keindahan alam bawah laut yang ada di Desa Teluk Bakau, para wisatawan bisa menyewa kapal dari pelabuhan yang ada di Desa Teluk Bakau. Selanjutnya untuk bisa menikmati keindahan alam bawah laut tersebut, para pengunjung bisa menggunakan beberapa wahana yang disediakan oleh pelaku usaha pariwisata, seperti snorkeling, diving, free dive dan banyak lagi.
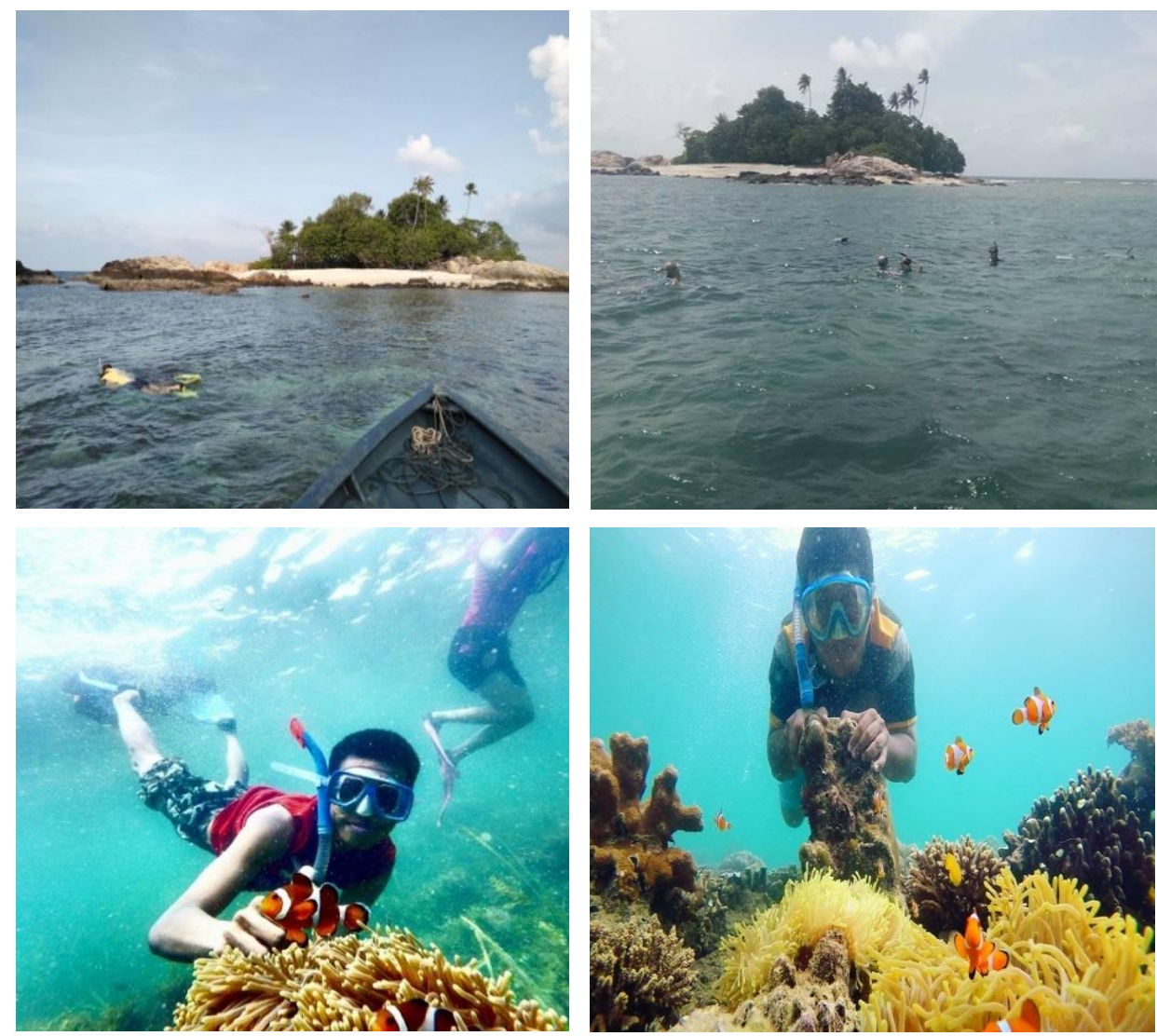

Gambar 2. Keindahan wisata bawah laut Desa Teluk Bakau

Untuk mencapai lokasi wisata bawah laut pengunjung hanya membutuhkan waktu sekitar 15 menit. Keindahan bawah laut yang bisa dinikmati selain airnya yang jernih adalah jenis-jenis karang dengan penghuninya yang beraneka ragam, salah satunya adalah ekosistem plankton atau ikan kecil yang sangat tergantung dengan flora yang hidup bersama dengan karang.

Hal tersebut sesuai dengan hasil wawancara mendalam (in-depth interview) dengan salah satu pengusaha pariwisata lokal Desa Teluk Bakau yang menyebutkan bahwa potensi

\footnotetext{
${ }^{8}$ Nurdin, 2016. Strategi Pengembangan Pariwisata Berbasis Masyrakat Di Pulau Samalona, Makassar. Jurnal Pariwisata Volume 03, Makassar.
}

Jurnal Socius: Journal of Sociology Research and Education Vol. 6, No.1, Th. 2019 
pantai dan laut merupakan potensi yang sangat bagus untuk pengembangan pariwisata berbasis masyarakat dimana masyarakat bisa memperoleh pendapatan bukan hanya dari hasil melaut.

Beragamnya potensi daya tarik wisata di Desa Teluk Bakau merupakan suatu kekuatan untuk pengembangan pariwisata. Keindahan saat matahari terbit (sunrise) dan terbenam (sunset) menjadi momen yang menarik bagi para wisatawan terutama bagi wisatawan yang memiliki hobi pemotretan (photography).

\section{Potensi Sosial Budaya}

Potensi budaya adalah semua hasil cipta, rasa dan karsa manusia baik berupa adat istiadat, kerajinan tangan, kesenian, peninggalan bersejarah nenek moyang berupa bangunan, monument, dan lain-lain. ${ }^{9}$ Masyarakat di Desa Teluk Bakau berasal dari suku Melayu. Wujud dari kebudayaan di Desa Teluk Baku ini terlihat dalam bahasa, perkawinan, kepercayaan dan sistem kemasyarakatannya. Budaya mempunyai peran penting dalam membuat produk wisata mempunyai keunikan dan diferensiasi tersendiri. Budaya juga menyediakan elemen 'hidup' dari suatu produk sehingga menghasilkan pengalaman tersendiri yang kian diminati oleh wisatawan.

Potensi sosial budaya tercermin dari keramah-tamahan masyarakat di Desa Teluk Bakau dengan sistem kekerabatan yang sangat erat dan ini menjadi daya tarik tersendiri. Wisatawan lebih senang mengunjungi suatu masyarakat yang ramah dan bisa dikunjungi oleh wisatawan asing tetapi dalam masyarakat ini mereka menerima kunjungan wisatawan dengan senang hati.

Upacara Mandi Safar umumnya disebut oleh suku Melayu dengan sebutan Safaran atau bulan naas yang masih dilakukan oleh masyarakat suku Melayu Desa Teluk Bakau, hal ini seperti menjadi suatu kewajiban bagi suku tersebut, akan tetapi bukan bagian dari kewajiban agama Islam. Sehingga orang Melayu Desa Teluk Bakau hanya sebagian yang masih melakukannya.

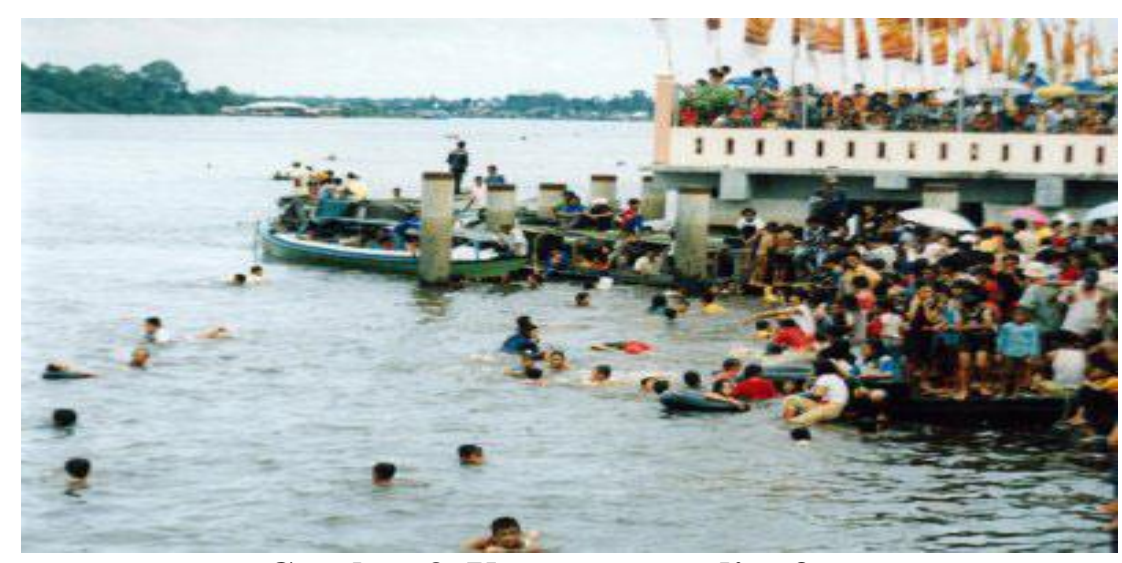

Gambar 3. Upacara mandi safar

Upacara mandi safar yang dilakukan pada bulan Safar, umumnya di muara sungai maupun di gang-gang yang mempunyai paret-paret kecil dan juga di dalam rumah. Keluarga besar di dalam sebuah perkampungan yang masih mempunyai adat istiadat yang kuat, jika tidak dilakukan pada tempat terbuka maka ada juga yang melakukannya di dalam atau pada tempat yang tertutup pada umumnya air yang disediakan adalah air khusus yang sudah dibacakan oleh tetua kampung.

\footnotetext{
${ }^{9}$ Nurdin, 2016. Strategi Pengembangan Pariwisata Berbasis Masyrakat Di Pulau Samalona, Makassar. Jurnal Pariwisata Volume 03, Makassar.
}

Jurnal Socius: Journal of Sociology Research and Education Vol. 6, No.1, Th. 2019

ISSN: Online 2442-8663 - Print 2356-4180

Copyright $\odot 2019$, Jurnal Socius 
Tokoh masyarakat (Tok Sambas) mengungkapkan bahwa kepercayaan masyarakat dengan mandi Safar akan menghilangkan kesialan pada anggota tubuh dan memohon keselamatan atas bala yang datang pada bulan tersebut. Ketentuan mandi Safar dengan kesepakatan bersama-sama warga daerah, perkampungan dengan menuju pada suatu lokasi tempat permandian dan berbekal berbagai keperluan untuk makan di tempat tersebut. Unsur budaya ini bisa diangkat sebagai salah satu daya tarik wisata karena potensi nilai-nilai budaya masyarakat tercermin dari kesenian yang mereka pertontonkan. Berdasarkan hasil wawancara tersebut upacara mandi safar dapat dilestarikan dan dikembangkan menjadi suatu daya tarik wisata budaya.

Atraksi lain yang dimiliki desa Teluk Bakau adalah permainan Jong. Permainan rakyat khas melayu ini masih bisa ditemukan di tengah masyarakat melayu, termasuk masyarakat melayu Desa Teluk Bakau. ${ }^{10}$ Jong merupakan permainan dengan menggunakan replikas perahu layar, perahu tersebut juga bisa berlayar ratusan meter. Jong memiliki panjang 1,5 meter, sedangkan tinggi layar mencapai 2 meter. Sedangkan lebar perahu hanya sejengkal orang dewasa. Jong biasanya terbuat dari jenis kayu pilihan yaitu kayu pulai. ${ }^{11}$

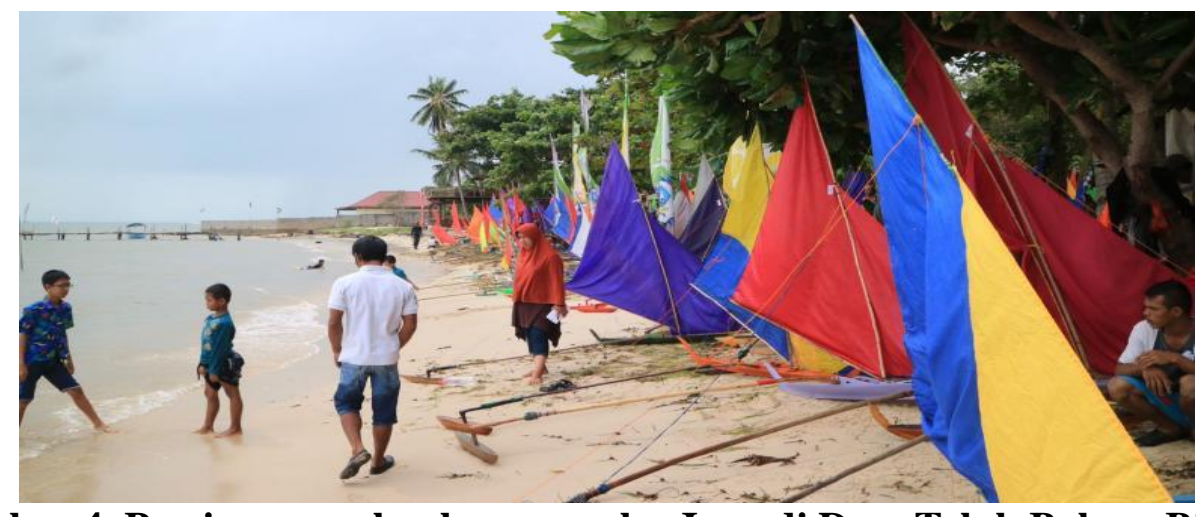

\section{Gambar 4. Persiapan perlombaan perahu Jong di Desa Teluk Bakau, Bintan}

Cara memainkannya adalah dengan mengandalkan tiupan angin yang kencang. Biasanya para pehobi jong memilih lokasi pantai untuk menguji ketangguhan jong miliknya. Jong dibawa dan diletakkan di atas laut, kemudian dilepaskan begitu saja. Hembusan angin yang kencang akan membawa jong mendarat hingga ke bibir pantai. Jong tidak bisa berdiri begitu saja. Harus disangga dengan penyeimbang. Penyeimbang ini berupa sebuah kayu memanjang yang diberikan pemberat pada salah satu sisinya. Bentuknya mirip seperti penyeimbang yang digunakan oleh perahu layar asli.

Sejarah permainan Jong ini konon berasal dari sebuah kegiatan ritual. Pada jaman dahulu orang-orang dari etnis Tionghoa sering memberikan sesaji ke tengah lautan. Dalam sesaji tersebut terdapat sebuah kue bernama Jong Kong. Sesaji ini dibawa dengan sebuah perahu kecil hingga hanyut tak terlihat lagi. Perahu mini tersebut justru menarik perhatian orang Melayu yang melihatnya. Kemudian oleh orang Melayu perahu tersebut dijadikan sebagai permainan yang menyenangkan. Nama permainannya diambil dari ritual Jong Kong yang dilakukan oleh etnis Tionghoa tersebut.

Di pesisir pantai Desa Teluk Bakau ini, sering diadakan festival Jong setiap tahunnya, sehingga menarik perhatian para pehobi Jong dari berbagai pulau, datang untuk memeriahkan kegiatan ini. Termasuk juga, para wisatawan lokal maupun asing ikut menyaksikan langsung kegiatan festival Jong yang diadakan oleh masyarakat Desa Teluk Bakau.

${ }^{10} \mathrm{http}: / /$ detiktipikornews.com/dari-250-peserta-jong-race-bertumpah-ruah-di pantai-teluk-bakau-bintan/

Jurnal Socius: Journal of Sociology Research and Education Vol. 6, No.1, Th. 2019

ISSN: Online 2442-8663 - Print 2356-4180

Copyright $\odot 2019$, Jurnal Socius 
Dengan adanya potensi tersebut maka akan melengkapi daya tarik wisata yang ada di Desa Teluk Bakau termasuk potensi alamnya, sehingga wisatawan akan merasa nyaman dan betah untuk tinggal di Desa Teluk Bakau. Potensi alam dan sosial budaya merupakan kekuatan sekaligus peluang bagi Desa Teluk Bakau menjadi destinasi pariwisata yang berkualitas.

\section{Partisipasi Masyarakat Lokal dalam Tahap Perencanaan}

Parameter yang digunakan untuk menentukan derajat partisipasi masyarakat dalam tahap perencanaan adalah keterlibatan dalam identifikasi masalah, perumusan tujuan, dan pengambilan keputusan terkait pengembangan desa wisata. Salah satu tokoh masyarakat (Rahmat) mengungkapkan bahwa bahwa sebagian besar masyarakat Desa Teluk Bakau tidak dilibatkan dalam identifikasi masalah dan tidak ikut terlibat dalam pengambilan keputusan terkait pengembangan desa wisata. Mereka tidak pernah diajak berdialog dalam mengidentifikasi kebutuhan masyarakat lokal.

"Setiap kali ada kegiatan rapat dalam membahas terkait pengembangan dan pembangunan pariwisata di Desa ini, kami selaku masyarakat jarang sekali diundang, paling yang undang $R T$ dan $R W$, yang lebih parah lagi apabila kami ikut rapat dan mengusulkan pendapat, tak pernah di hiraukan baik itu oleh pihak pemerintah Desa maupun pemerintah Daerah”. (Wawancara, 28 April 2018)

Hal ini terjadi, karena (1) gagasan pengembangan desa wisata dilakukan oleh Pemerintah Kabupaten Bintan tanpa melibatkan masyarakat sebagai pemilik sumber daya, sehingga masyarakat Desa Teluk Bakau kurang memahami latar belakang pengembangan desa wisata, (2) masyarakat lokal hanya menjalankan apa yang diprogamkan oleh pemerintah, misalnya, kesediaan menerima kedatangan wisatawan dan menyerahkan lahan untuk dibangun fasilitas wisata, dan (3) masyarakat lokal tidak berkekuatan untuk berpartisipasi aktif dalam arti ikut memberi warna terhadap keputusan yang akan diambil oleh penguasa.

Pada tahap ini, partisipasi yang dilakukan oleh masyarakat tergolong semu. Benefit yang diperoleh dari bentuk partisipasi yang dilakukan tidak menunjukkan hasil yang signifikan, bahkan umpan balik yang disampaikan oleh masyarakat lokal atas keputusan yang diambil oleh penguasa sering diabaikan. Padahal substansi dalam pengembangan desa wisata berbasis masyarakat, partisipasi yang dilakukan oleh masyarakat Desa Teluk Bakau seharusnya bersifat aktif dan langsung. Namun, selalu dihadang oleh keputusan penguasa yang bersifat top down. Mekanisme seperti ini menjadikan masyarakat Desa Teluk Bakau tidak terbiasa berpartisipasi. Ketergantungan terhadap pemerintah dan investor tinggi. Kondisi ini berakibat pada kurangnya respon, antusiame, dan keterlibatan masyarakat dalam pengelolaan dan pengembangan asetaset di wilayah mereka.

Salah satu tokoh masyarakat (Bapak Efendi) mengungkapkan bahwa dalam hal keaktifan masyarakat Desa Teluk Bakau, kehadiran warga dalam pertemuan desa cukup antusias. Walaupun warga masyarakat banyak yang hadir dalam setiap pertemuan, pada umumnya mereka mengaku tidak terlibat dalam pengambilan keputusan perihal pengembangan desa wisata. Dalam hal keterwakilan masyarakat pada rapat-rapat, biasanya perangkat desa hanya mengundang beberapa warga yang merupakan perwakilan tiap-tiap RT.

"Kami selaku warga Desa Teluk Bakau, kalau di undang untuk hadir membahas masalah pembangunan pariwisata pasti semangat untuk hadir, karna Desa Teluk Bakau ini potensi wisatanya sangat menjajikan untuk perkembangan ekonomi masyarakat, tapi pada kenyataannya yang di undang setiap rapat adalah ketua karang taruna, ketua $R W$, ketua $R T$, pemuda-pemuda yang dianggap berpendidikan, sehingga kami-kami ini di abaikan”. (Wawancara, 28 April 2018)

Jurnal Socius: Journal of Sociology Research and Education Vol. 6, No.1, Th. 2019 
Isu menarik lainnya adalah keterwakilan masyarakat. Meskipun peserta yang hadir dalam perencanaan pengembangan desa wisata berasal dari berbagai latar belakang, hal ini belum mencerminkan keterwakilan. Pertemuan-pertemuan itu biasanya dihadiri oleh tokoh masyarakat, karang taruna, instansi terkait dan warga masyarakat yang berpendidikan, misalnya guru, pegawai negeri sipil, dan rohaniawan, yang secara resmi diundang oleh kepala desa. Kondisi ini mengindikasikan bahwa pengembangan desa wisata belum sepenuhnya melibatkan seluruh lapisan masyarakat karena dominasinya adalah golongan menengah ke atas, termasuk para pelajar, orang berpendidikan, dan para pemimpin informal.

\section{Partisipasi Masyarakat Lokal Dalam Tahap Implementasi}

Parameter Partisipasi masyarakat dalam tahap implementasi adalah keterlibatan di dalam pengelolaan usaha-usaha pariwisata, misalnya, sebagai pengelola penginapan, pengelola rumah makan, pemandu wisata, karyawan hotel, karyawan hotel, dan pengelola atraksi wisata. Ketua Karang Taruna Desa Teluk Bakau (Roy Sandara) mengungkapkan bahwa keterlibatan masyarakat lokal dalam tahap implentasi dalam arti pemanfaatan peluang terlihat minim. Sekalipun wujud partisipasi itu ada, bentuknya lebih pada pengelolaan usaha-usaha berskala kecil.

"Kalau bicara soal keterlibatan masyarakat lokal dalam pemanfaatan peluang di Desa Teluk Bakau ini, bisa dibilang sangat minim, kalau pun ada, pengelolaannya lebih pada usaha-usaha kecil, seperti membuka warungwarung makan kecil di pinggir jalan, untuk itupun pembelinya karyawan hotel, bukan wisatawan, yang jelas masyarakat tidak memiliki modal yang besar untuk mengembangkan usaha yang besar, ditambah lagi pihak swasta mengambil alih usaha berskala kecil yang pada mulanya dikelola masyarakat lokal, sehingga ekonomi masyarakat lokal tidak lancar”. (Wawancara, 28 April 2018)

Hal ini terlihat kontras dengan partisipasi masyarakat luar yang memonopoli usaha berskala besar. Misalnya, dari tujuh fasilitas wisata berupa 7 buah sarana akomodasi enam di antaranya dikelola oleh orang asing, dan hanya 1 buah yang dikelola oleh masyarakat lokal yaitu snorkling. Penyebabnya adalah karena peluang usaha tersebut memerlukan modal besar, risiko bisnis yang tinggi, persaingan ketat, dan menuntut kompetensi yang tinggi. Masyarakat Desa Teluk Bakau dengan kompetensi bisnis yang rendah dan keterbatasan modal menyebabkan mereka tidak mampu bersaing dengan para pemilik modal besar yang umumnya berasal dari luar desa. Ironisnya, para pemilik modal besar tidak hanya menekuni usaha berskala besar, juga mengambil alih usaha berskala kecil yang pada mulanya dikelola masyarakat lokal. Akibatnya, sebagian besar hasil usaha-usaha tersebut tidak terdistribusi di tingkat lokal melainkan mengalir ke luar desa.

Intervensi modal asing yang merambah sampai wilayah pedesaan, menyebabkan terjadinya proses marginalisasi posisi sosial ekonomi masyarakat Desa Teluk Bakau. Pengembangan desa wisata dipandang sebagai neokapitalis yang hanya mengeksploitasi masyarakat lokal, sementara keuntungan dan manfaat pengembangan desa wisata sebagian besar dinikmati kaum kapitalis. Kesenjangan pendapatan dan kesejahteraan antar lapisan masyarakat semakin besar, pada akhirnya, masyarakat lokal tetap berada di posisi marginal dalam usaha yang justru terjadi di wilayahnya sendiri. Kondisi ini mengindikasikan bahwa pengembangan desa wisata belum bermanfaat ekonomis bagi masyarakat Desa Teluk Bakau.

\section{Partisipasi Masyarakat Lokal dalam Tahap Pengawasan}

Masyarakat lokal memiliki peran kontrol yang sangat substansial dalam pengembangan desa wisata karena kontrol terhadap proses pengambilan keputusan harus diberikan kepada

Jurnal Socius: Journal of Sociology Research and Education Vol. 6, No.1, Th. 2019 
mereka yang nantinya menanggung akibat pelaksanaan pengembangan termasuk kegagalan atau dampak negatif yang terjadi akibat pengembangan desa wisata. Oleh karena itu, kewenangan pengambilan keputusan harus diberikan kepada masyarakat lokal. Parameter partisipasi masyarakat dalam pengawasan adalah keterlibatan dalam tim pengawasan berikut kewenangan yang dimiliki.

Kepala dusun Desa Teluk Bakau (Arsyad) mengungkapkan bahwa bahwa keterlibatan masyarakat lokal dalam melakukan pengawasan terhadap pengembangan desa wisata terlihat minim.

"Bagaimana kami ingin mengawasi perkembangan pembangunan pariwisata di Desa Teluk Bakau ini, kalau kami sibuk-sibuk di tuduh jadi mata-mata akhirnya ribut dengan pemerintah desa dan pemerintah daerah, akhirnya kita masyarakat kecil ini juga yang kalah”. (Wawancara, 28 April 2018)

Pada tahap ini, perencanaan pengembangan dilakukan oleh pemerintah secara topdown, sehingga masyarakat tidak berkompotensi untuk melakukan pengawasan, disamping itu pengawasan oleh masyarakat dimaknai oleh pemerintah sebagai tindakan memata-matai program yang dilakukan pemerintah sehingga berujung terjadinya konflik. Sedangkan pengawasan yang bersifat lebih kompleks seperti pelanggaran tata ruang, sebagian besar warga bersikap tidak peduli, padahal secara substansi seharusnya masyarakat lokal ikut mengawasi. Selama ini pengawasan yang bersifat kompleks hanya dilakukan oleh segelintir masyarakat yang kritis termasuk elite masyarakat lokal dan tersebut juga tidak memberikan dampak yang positif dikarenakan masyarakat tidak memiliki kekuatan untuk menentang kebijakan pemerintah yang jelas merugikan masyarakat.

\section{Partisipasi Masyarakat Lokal dalam Tahap Pelestarian}

Lingkungan merupakan sarana utama yang harus diperhatikan bagi berhasilnya pengembangan pariwisata. Kebersihan lingkungan adalah kebersihan tempat tinggal, tempat bekerja, dan berbagai sarana umum keamanan dan kenyamanan lingkungan desa serta menjaga kebersihan dan melestarikan lingkungan desa. Kenyamanan dan keamanan menjadi kondisi yang sangat penting dalam industri pariwisata. Aspek tersebut pada dua dekade terakhir telah menjadi isu yang semakin besar dan mempunyai dampak yang sangat besar terhadap keberlangsungan aktivitas perjalanan dan pariwisata. ${ }^{12}$

Ancaman kenyamanan dan keamanan wisatawan dapat dipengaruhi dan disebabkan oleh beragam faktor, seperti aksi teroris, konflik lokal, bencana alam, perilaku sosial masyarakat dan penyakit menular sehingga hal tersebut dapat menyebabkan menurunnya rasa aman bagi wisatawan. Kenyamanan dan keamanan bagi wisatawan merupakan salah satu faktor yang menentukan keputusan untuk melakukan suatu perjalanan ke suatu destinasi pariwisata.

Ketua GMPL (Gerakan Masyarakat Peduli Lingkungan) Desa Teluk Bakau (Syukur) mengungkapkan Bahwa keamanan di Desa Teluk Bakau bisa dikatakan aman. Gangguan lain yang bisa menjadi ancaman adalah konflik internal masyarakat Desa juga bisa terkontrol, sebab masyarakat di Desa Teluk Bakau masih memiliki hubungan kekerabatan yang sangat dekat. Jadi masyarakat Desa Teluk Bakau merasa aman dan nyaman dengan begitu wisatawan pun akan merasa nyaman selama berwisata di Desa Teluk Bakau. Dengan kondisi tersebut akan menjadi kekuatan tersendiri Bagi Desa Teluk Bakau dalam pengembangan pariwisata dan secara khusus menunjang pengembangan pariwisata berbasis masyarakat lokal.

\footnotetext{
${ }^{12}$ Kövári, István dan Zimányi, Krisztina. 2011. Safety and Security in the Age of Global Tourism (The changing role and conception of Safety and Securityin Tourism). Budapest: Agroinform Publishing House.
}

Jurnal Socius: Journal of Sociology Research and Education Vol. 6, No.1, Th. 2019 
"Keamanan di Desa Teluk Bakau ini, biae saya katakan aman karena Desa Teluk Bakau ini tidak begitu luas, jadi orang yang datang dan pergi bisa diketahui, kalau untuk menjaga keamanan memang tak pernah diadakan poskalmling di sini, namun dari masyarakat sendiri saling bekerja sama dalam menjaga keamanan di Desa Teluk Bakau ini, dan masyarakat dari setiap RT saling kompak dan atas dasar kesadaran bersama untuk menjaga keamanan. Apalagi masyarakat Desa Teluk Bakau rata-rata masih ada hubungan saudara, jadi perkelahian atau pertengkaran antar warga bisa terkendali sehingga masyarakat merasa aman dan nyaman, begitupun wisatawan akan nyaman selama di Desa Teluk Bakau,". (Wawancara, 28 April 2018)

Kondisi aman yang sudah tercipta harus dihargai dan diapresiasi sebagai salah satu bentuk partisipasi masyarakat dalam pengembangan desa wisata berbasis partisipasi masyarakat lokal di Desa Teluk Bakau. Walaupun hal tersebut masyarakat tidak secara langsung berpartisipasi dalam aktivitas kepariwisataan. Meskipun tidak ada kegiatan patroli keliling di Desa Teluk Bakau namun, dalam menjaga keamanan di Desa Teluk Bakau yang dilakukan oleh masyarakat Desa Teluk Bakau adalah setiap RT saling bekerjasama dengan penuh kesadaran untuk saling peka terhadap ancaman-ancaman yang bisa saja sewaktu-waktu muncul sehingga bisa mengganggu keamanan dan kenyamanan lingkungan.

Dalam menjaga dan melestarikan kebersihan lingkungan ada banyak macam cara misalnya dengan membuang sampah pada tempatnya serta menata lingkungan sekitar sehingga tampak bersih dan rapi. Beberapa faktor yang mempengaruhi timbulnya sampah adalah jumlah penduduk, sistem pengumpulan dan pembuangan sampah, faktor geografis dan kebiasaan masyarakat.

Kepala dusun Desa Teluk Bakau (Bapak Arsyad) mengungkapkan bahwa masyarakat berpartisipasi dalam menjaga kebersihan lingkungan Desa Teluk Bakau walaupun pemilahan sampah belum dilakukan dan ini menjadi kendala juga bagi masyarakat karena tempat pengumpulan/pembuangan sampah dan pengangkutan sampah di Desa Teluk Bakau belum dibuat sistem atau pengelolaan yang baik dan tepat.

"Dalam menjaga kebersihan di Desa Teluk Bakau ini, masyarakat sudah ikut serta, paling tidak lingkungan di kediaman mereka masing-masing, cuma yang menjadi kendalanya sekarang ini tidak ada tempat pengumpulan dan pembuangan sampah karena di Desa Teluk Bakau ini masyarakat tidak tau ingin dibuang ke mana sampah-sampah itu, jadi kebanyakan masyarakat disini, sampah itu dibakar atau ditanam". (Wawancara, 28 April 2018)

Partisipasi masyarakat baik secara langsung maupun tidak langsung mejadi penunjang dalam pengembangan desa wisata berbasis partisipasi masyarakat lokal di Desa Teluk Bakau. Sehingga ini bisa menjadi pertimbangan bagi pemerintah dalam mendukung pengembangan tersebut, dengan membuat regulasi dan program yang tepat, sehingga dapat memberikan keuntungan bagi masyarakat setempat.

\section{Model Pengembangan Desa Wisata Berbasis Masyarakat Lokal}

Untuk melihat keterlibatan masyarakat dalam pengembangan desa wisata di Desa Teluk Bakau perlu diketahui tahapan-tahapan yang dilakukan dalam proses pengembangan desa wisata. Sesuai teori yang digunakan dalam penelitian ini yaitu teori partisipasi yang diadaptasi dari Cohen dan Uphoff (1977), terdapat 4 tahap dalam proses pembangunannya yaitu mulai dari perencanaan, pelaksanaan (implementasi), pengawasan, dan pelestarian. Konsep ini memberikan makna bahwa masyarakat akan berpartisipasi secara sukarela apabila mereka dilibatkan sejak awal dalam proses pembangunan melalui program pemberdayaan. Ketika

Jurnal Socius: Journal of Sociology Research and Education Vol. 6, No.1, Th. 2019 
mereka mendapatkan manfaat dan merasa memiliki terhadap program pemberdayaan, maka dapat dicapai suatu keberlanjutan dari program pemberdayaan.

Berdasarkan hasil observasi dan wawancara mendalam dengan semua narasumber (10 narasumber), partisipasi masyarakat lokal di Desa Teluk Bakau, dalam pengembangan desa wisata sangat minim. Mengacu pada teori partisipasi Cohen dan Uphoff (1977), minimnya pasrtisipasi masyarakat lokal Desa Teluk Bakau dalam pengembangan desa wisata dapat dilihat dari tahap perencanaan, pelaksanaan (implementasi), pengawasan dan pelestarian.

Berdasarkan pada tahap perencanaan dalam pengembangan desa wisata di Desa Teluk Bakau, maka pada tahap ini partisipasi masyarakat Desa Teluk Bakau terlihat minim dikarenakan masyarakat Desa Teluk Bakau tidak dilibatkan dalam identifikasi masalah dan tidak ikut terlibat dalam pengambilan keputusan terkait pengembangan desa wisata. Hal ini terjadi karena, (1) gagasan pengembangan desa wisata dilakukan oleh pemerintah Kabupaten Bintan tanpa melibatkan masyarakat sebagai pemilik sumber daya, sehingga masyarakat Desa Teluk Bakau kurang memahami latar belakang pengembangan desa wisata, (2) masyarakat lokal hanya menjalankan apa yang diprogramkan oleh pemerintah, misalnya kesediaan menerima kedatangan wisatawan dan menyerahkan lahan untuk dibangun fasilitas wisata, (3) masyarakat tidak berkekuatan untuk berpartisipasi aktif dalam arti ikut memberi warna terhadap keputusan yang akan diambil oleh penguasa.

Pada tahap pelaksanaan (implementasi) dalam pengembangan desa wisata di Desa Teluk Bakau partisipasi masyarakat Desa Teluk Bakau terlihat minim yang disebabkan karena (1) peluang usaha memerlukan modal besar, (2) resiko bisnis yang tinggi, (3) persaingan yang cukup ketat, (4) menuntut kompetensi yang tinggi.

Pada tahap pengawasan dalam pengembangan desa wisata di Desa Teluk Bakau terlihat minim, dikarenakan (1) perencanaan pengembangan dilakukan oleh pemerintah secara topdown, sehingga masyarakat tidak berkompetensi untuk melakukan pengawasan, (2) pengawasan oleh masyarakat dimaknai oleh pemerintah sebagai tindakan memata-matai program yang dilakukan pemerintah sehingga berujung terjadinya konflik, (3) masyarakat tidak memiliki kekuatan untuk menentang kebijakan pemerintah yang jelas merugikan masyarakat.

Pada tahap pelestarian dalam pengembangan desa wisata di Desa Teluk Bakau cukup antusias terlihat dalam bentuk, (1) adanya kesadaran masyarakat dalam untuk berpartisipasi menjaga keamanan desa. Meskipun tidak ada kegiatan patroli keliling di Desa Teluk Bakau, namun dalam menjaga keamanan di Desa Teluk Bakau yang dilakukan oleh masyarakat adalah dengan cara setiap RT saling bekerjasama dengan penuh kesadaran untuk saling peka terhadap ancaman-ancaman yang bisa saja sewaktu-waktu muncul, (2) meskipun pemilahan sampah belum dilakukan dan ini menjadi masih menjadi kendala bagi masyarakat karena tempat pengumpulan/pembuangan sampah dan pengangkutan sampah di Desa Teluk Bakau belum dibuat sistem atau pengelolaan yang baik dan tepat, namun tetap terlihat adanya kesadaran masyarakat untuk berpartisipasi dalam menjaga kebersihan lingkungan dengan cara membakar atau menanam sampah-sampah dengan tujuan agar lingkungan sekitar terlihat bersih dan tidak kumuh.

Harapan masyarakat Desa Teluk Bakau dalam pengembangan desa wisata ke depan adalah (1) pengembangan desa wisata harus berpedoman pada kearifan lokal yang berlaku di Desa Teluk Bakau, (2) masyarakat harus terlibat penuh dalam pengembangan desa wisata, (3) menghargai hak-hak masyarakat lokal, (4) memperhatikan kelestarian lingkungan dan ruang terbuka, (5) ada kelembagaan otonom dan mandiri yang dibentuk oleh masyarakat lokal di bawah tanggung jawab desa.

Mengacu pada teori partisipasi, agar program pengembangan desa wisata berbasis partisipasi masyarakat lokal dapat terlaksana, dirumuskan hal-hal sebagai berikut. (1)

Jurnal Socius: Journal of Sociology Research and Education Vol. 6, No.1, Th. 2019 
masyarakat lokal menjadi sentral dan menjadikan subjek dari semua proses pengembangan desa wisata. Dengan menempatkan masyarakat sebagai sentral diharapkan partisipasi masyarakat sebagai pemilik sumber daya pariwisata akan terdorong dan mampu menyejahterakan masyarakat lokal, (2) pengembangan desa wisata membutuhkan adanya kemitraan yang solid antara tiga unsur utama, yaitu pemerintah, swasta, dan perguruan tinggi, yang masyarakat lokal menjadi pemangku kepentingan dari kerja sama tersebut. The golden triangle hanya dapat berhasil diterapkan apabila pemprakarsa kemitraan mengerti hal-hal yang menjadi pemicu terjadinya kerja sama, (3) perlu dibentuk badan pengelola yang otonom dan mandiri, yang saling berinteraksi, memberikan umpan balik pelaksanaan untuk mengoreksi diri pada setiap jenjang organisasi, (4) keputusan dan inisiatif untuk memenuhi kebutuhan masyarakat lokal dibuat ditingkat lokal oleh warga masyarakat yang memiliki identitas yang diakui peranannya sebagai partisipan dalam proses pengambilan keputusan, (5) fokus utama pengembangan desa wisata adalah memperkuat kemampuan masyarakat lokal dalam mengarahkan dan mengatasi aset-aset yang ada pada masyarakat lokal untuk memenuhi kebutuhannya.

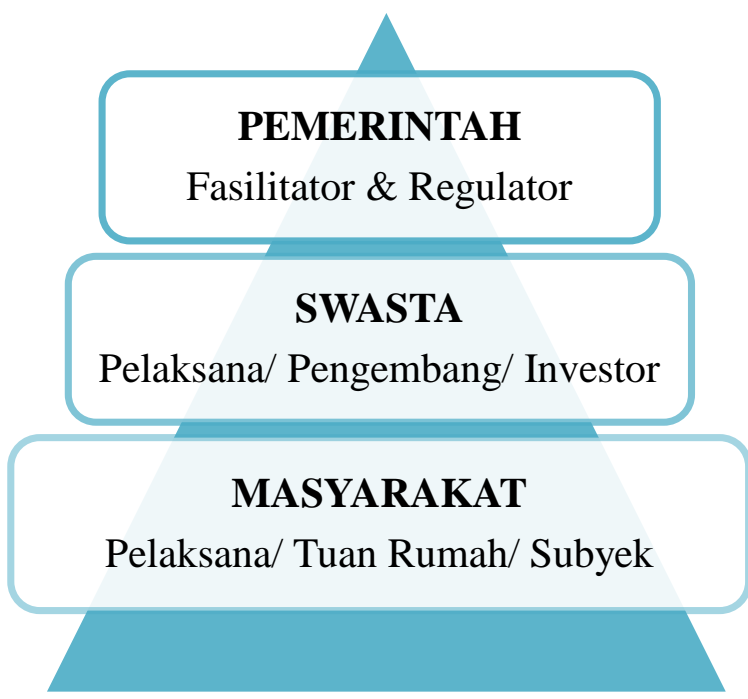

\section{Gambar 6. Konsep pemangku kepentingan dalam pengembangan pariwisata}

Pengembangan desa wisata membutuhkan adanya kemitraan yang solid antara tiga unsur utama, yaitu pemerintah, swasta, dan masyarakat, yang masyarakat lokal menjadi pemangku kepentingan dari kerja sama tersebut. The golden triangle tersebut hanya dapat berhasil diterapkan apabila pemprakarsa kemitraan mengerti hal-hal yang menjadi pemicu terjadinya kerja sama. ${ }^{13}$

Peran dan Kewenangan Pemerintah, yaitu (1) melakukan pembinaan kualitas produk dan kemasan kerajinan dan kuliner khas desa sebagai unsur kenangan wisata, (2) melakukan penataan dan konservasi lingkungan kawasan yang menjadi ciri khas desa wisata, (3) melakukan perbaikan/pengadaan infrastruktur persampahan dan sanitasi, (4) melakukan gerakan masyarakat untuk mewujudkan sapta pesona, (5) melakukan pembuatan informasi dan fasilitas kepariwisataa, (6) melakukan perbaikan/peningkatan kualitas ruang publik, pedestrian dan landscape desa/lingkungan untuk mendukung sapta pesona, dan (7) dukungan

\footnotetext{
${ }^{13}$ Wearing, S.L. and Donald, Mc. 2001. "The Development of Community Based Tourism: Re Thinking The Relationsgip between Tour Operators and Development Agents as intermediaries in rural and isolated area Communities." Journal of Sustainable Tourism.
}

Jurnal Socius: Journal of Sociology Research and Education Vol. 6, No.1, Th. 2019 
pemberdayaan terhadap kelompok sadar wisata (Pokdarwis) dalam pelestarian lingkungan pariwisata (kawasan pesisir pantai).

Peran dan kewenangan swasta (Investor, Perguruan Tinggi, LSM, pelaku pariwisata lainnya), yaitu (1) melakukan promosi terintegrasi antar pengelola objek wisata untuk menggerakkan kunjungan wisatawan antar objek wisata, (2) pembuatan dan pemasaran paketpaket wisata yang kompetitif yang terjangkau masyarakat, (3) pelatihan kewirausahaan, pelatihan keterampilan individual terkait usaha di bidang pariwisata (pelatihan bahasa Inggris, pelatihan hospitality, pelatihan mengenal budaya, dan karakteristik wisatawan dalam dan luar negeri), (4) pengembangan kelompok usaha bersama masyarakat, dan (5) menjalankan bisnis perhotelan, restoran, suvenir, dan lain-lain.

Peran masyarakat lokal, yaitu (1) menyediakan sebagian besar atraksi sekaligus menentukan kualitas produk wisata. Pengelolaan lahan pertanian secara tradisional, upacara adat, kerajinan tangan dan kebersihan merupakan beberapa contoh peran yang memberikan daya tarik bagi pariwisata, (2) pelaku budaya, misalnya, kesenian yang menjadi salah satu daya tarik wisata dan (3) penyedia akomodasi dan jasa pemandu wisata, penyediaan tenaga kerja, produk makanan khas, kerajinan lokal, kesenian lokal, dan sebagainya.

Selanjutnya sesuai dengan analisis SWOT yang menjelaskan bahwa analisis SWOT adalah proses identifikasi berbagai faktor secara sistematis guna menentukan rumusan yang tepat dan melakukan strategi perusahaan yang terbaik. Analisis ini berdasarkan pada logika yang dapat memaksimalkan kekuatan (Strengths) dan peluang (Opportunities), namun secara bersamaan dapat meminimalkan kelemahan (Weaknesses) dan ancaman (Threats). Proses pengambilan keputusan strategis perusahaan selalu berkaitan erat dengan pengembangan misi, visi, tujuan, strategi serta kebijakan perusahaan. Oleh karenanya perencanaan yang strategis sangat memerlukan analisa-analisa dari masing masing SWOT ini (kekuatan, kelemahan, peluang, dan ancaman) di lingkungan perusahaan saat ini. ${ }^{14}$

Berdasarkan analisis SWOT dalam pengembangan desa wisata berbasis partisipasi masyarakat lokal di Desa Teluk Bakau terdiri dari beberapa faktor yang dapat menjadi kekuatan dan kelemahan. Faktor yang menjadi kekuatan di antaranya: (1) keindahan alam, (2) sikap ramah tamah masyarakat lokal, (3) keunikan tradisi dan budaya masyarakat lokal. Faktor yang menjadi kelemahan adalah: (1) sumber daya manusia, (2) menejemen destinasi.

Kondisi lingkungan eksternal di Desa Teluk Bakau terdiri dari beberapa faktor yang dapat menjadi peluang dan ancaman dalam pengembangan desa wisata berbasis partisipasi masyarakat lokal di Desa Teluk Bakau. Faktor yang dapat menjadi peluang diantaranya adalah: (1) kemajuan teknologi dan telekomunikasi, (2) jarak Desa Teluk Bakau dengan pelabuhan internasional Sri Bintan Pura Tanjungpinang. Faktor yang menjadi ancaman adalah kurang dilibatkannya masyarakat melibatkan masyarakat dalam pengelolaan usaha-usaha pariwisata.

Berdasarkan kondisi lingkungan internal dan eksternal di Desa Teluk Bakau serta jumlah kunjungan wisatawan, maka strategi umum (grand strategy) yang bisa diterapkan adalah strategi penetrasi pasar dan pengembangan produk wisata. Strategi penetrasi pasar adalah strategi memperluas pasar (market share) suatu produk atau jasa melalui usaha-usaha pemasaran yang lebih besar. ${ }^{15}$

Berdasarkan kekuatan, kelemahan, peluang dan ancaman dalam pengembangan pariwisata berbasis masyarakat di Desa Teluk Bakau, maka melalui matriks SWOT akan ditemukan beberapa strategi khusus yang dapat mendukung kelayakan pengembangan desa wisata berbasis partisipasi masyarakat lokal di Desa Teluk Bakau. Alternatif pengembangan

\footnotetext{
${ }^{14}$ Rangkuti, Freddy. (2009). Strategi Promosi yang Kreatif dan Analisis Kasus Integrated Marketing Communication. Jakarta: PT. Gramedia Pustaka Utama.

${ }^{15}$ Umar, Husein. 2005. Metode Penelitian untuk Skripsi, Tesis dan Bisnis. Jakarta: PT. Raja Grafindo Persada.
}

Jurnal Socius: Journal of Sociology Research and Education Vol. 6, No.1, Th. 2019

ISSN: Online 2442-8663 - Print 2356-4180

Copyright $\odot 2019$, Jurnal Socius 
pariwisata berbasis masyarakat di Pulau Samalona sebagai strategi khusus, yang merupakan opsi pengembangan yang dapat diterapkan yaitu; (1) Strategi pengembangan destinasi pariwisata, (2) Strategi pengembangan daya tarik wisata, (3) Strategi peningkatan kualitas lingkungan, (4) Strategi pengembangan pariwisata berkelanjutan, (5) Strategi pengembangan promosi destinasi pariwisata, (6) Strategi pengembangan sumber daya manusia, dan (7) Strategi pengembangan kelembagaan dan manajemen destinasi serta melibatkan masyarakat dalam pengelolaan usaha-usaha pariwisata.

\section{Penutup}

\section{Kesimpulan}

Peran pemerintah dalam pengelolaan sumber daya pariwisata terlihat dominan. Padahal bila mengacu pada pendekatan tata kelola pemerintah yang bersih dan berkelanjutan peran pemerintah diharapkan menjadi fasilitator dengan memberikan peran dan manfaat yang lebih besar kepada masyarakat. Hal ini menunjukkan bahwa pembangunan pariwisata berbasis partisipasi masyarakat belum terwujud di wilayah ini. Masyarakat belum menjadi subjek pembangunan, tetapi masih menjadi objek pembangunan.

Masyarakat lokal khususnya masyarakat Desa Teluk Bakau perlu diajak untuk mendesain sendiri model pariwisata yang akan dikembangkan. Selama ini pariwisata yang dikembangkan di desa wisata tersebut tidak pernah di desain oleh mereka. Pariwisata yang dikembangkan didesain oleh orang luar desa. Masyarakat lokal terpinggirkan. Pengembangan desa wisata berjalan sesuai dengan kebutuhan masyarakat, harus ada jaminan masyarakat untuk terlibat di dalamnya. Untuk menjamin hal itu diperlukan kemauan politik pemerintah untuk mengurangi peranannya dalam pengembangan desa wisata dan memberikan peranan yang lebih besar kepada masyarakat dengan membuka ruang bagi masyarakat untuk berpartisipasi. Selama ini masyarakat terbiasa menjalankan apa yang diperintahkan oleh pemerintah dan tidak dibiasakan berpartisipasi.

\section{Saran}

Peningkatan partisipasi masyarakat terutama dalam perncanaan dan evaluasi kegiatan pariwisata, pada dasarnya tidak memadai yang disebabkan tidak terlibatnya peran masyarakat dalam proses pengembangan Desa Wisata pada saat perencanaan dan evaluasi, maka dari itu, Kepada Dinas Kebudayaan dan Pariwisata Kabupaten Bintan dan Stakeholder terkait selaku fasilitator diharapkan agar mengikutsertakan masyarakat serta memberikan bantuan akses permodalan dan akses pengembangan kapasitas masyarakat dalam proses pengembangan Desa Wisata Teluk Bakau.

Hal-hal yang bisa dilakukan oleh pihak Dinas Kebudayaan dan Pariwisata Kabupaten Bintan Stakeholder terkait selaku fasilitator adalah (1) melibatkan masyarakat dalam identifikasi masalah, perumusan tujuan, dan pengambilan keputusan terkait pengembangan desa wisata, (2) melibatkan masyarakat dalam pengelolaan usaha-usaha pariwisata, (3) melibatkan peran masyarakat terhadap kontrol yang sangat substansial dalam pengembangan desa wisata, (4) memberikan sosialisasi mengenai gerakan sadar wisata serta kampanye tentang kebersihan dan kelestarian lingkungan.

\section{Daftar Pustaka}

Abe, A. (2002). Perencanaan Daerah Partisipatif. Solo: Pondok Edukasi.

Arnstein, S.R.(1969). A Ladder Of Citizen Participation. JAIP, 35 (4), pp 216-224

Bungin, Burhan. (2008). Metodologi Penelitian Kualitatif. Jakarta: PT Raja Grafindo Persada.

Jurnal Socius: Journal of Sociology Research and Education Vol. 6, No.1, Th. 2019

ISSN: Online 2442-8663 - Print 2356-4180 
Alfi Husni, Safaat

Cohen, JM, dan N.T. Uphoff. (1977). Rural Development Participation. Cornell University RDCCIS: New York.

http://detiktipikornews.com/dari-250-peserta-jong-race-bertumpah-ruah-dipantai teluk-

bakau-bintan/ (Diakses pada 17 April 2018, pukul 15:20 Wib)

http://batamnews.co.id/berita-12915-uniknya-perahu-layar-jong-permainan khas-kepulauanriau.html (diakses pada 17 April 2018, pukul 16:03 Wib)

Kövári, István dan Zimányi, Krisztina. (2011). Safety and Security in the Age of Global Tourism (The cha nging role and conception of Safety and Security in Tourism). Buda pest: Agroinform Publishing House.

Lewis,J. (2003). Design Issues. In Qualitative ResearchPractice: a Guide for Social Science Student Researcher (eds.) Jane Ritchie and Janes Lewis. London: SAGE Publications.

Nurdin, 2016. Strategi Pengembangan Pariwisata Berbasis Masyarakat Di Pulau Samalona, Makassar. Jurnal Pariwisata, 3(1)

Rangkuti, Freddy. (2009). Strategi Promosi yang Kreatif dan Analisis Kasus Integrated Marketing Communication. Jakarta: PT. Gramedia Pustaka Utama.

Tosun, C. (2000). Limits to community participation in the tourism development process in developing countries. Turkey: Bilkert University.

Undang-Undang Republik Indonesia Nomor 10 Tahun 2009 tentang Kepariwisataan.

Umar, Husein. (2005). Metode Penelitian untuk Skripsi, Tesis dan Bisnis. Jakarta: PT. Raja Grafindo Persada.

Wearing, S.L. and Donald, Mc. (2001). The Development of Community Based Tourism: Re Thinking The Relationsgip between Tour Operators and Development Agents as intermediaries in rural and isolated area Communities. Journal of Sustainable Tourism.

Yoeti, Oka A. (2002). Perencanaan Strategis Pemasaran Daerah Tujuan Wisata. Jakarta: PT. Pradnya Paramita. 